\title{
Comparison of the hemostatic suture with non-suture cold- knife conization methods for cervical surgery
}

\author{
Servikal ameliyatlarda hemostatik sütürlü ve sütürsüz soğuk konizasyon \\ yöntemlerinin karşılaştırması
}

\section{Tuğba Gürbüz ${ }^{1}$, (1) Oğuz Devrim Yardımcı}

${ }^{1}$ Medistate Hospital, Gynecology and Obstetrics Clinic, İstanbul Turkey

${ }^{2}$ Medeniyet Univercity Göztepe Training and Research Hospital, Gynecology and Obstetrics Clinic, İstanbul Turkey

Cite this article as / Bu makaleye atıf için: Gürbüz T, Yardımcı OD. Comparison of the hemostatic suture with non-suture cold-knife conization methods for cervical surgery. J Health Sci Med 2020; 3(4): 362-366.

\begin{abstract}
Aim: The primary purpose of this study is to compare the suture with non-suture cold-knife after conization methods.

Material and Method: The study included 172 women who underwent the cold-knife conization. In the first group, patients underwent cold-knife conization without sutures, and in the second group, patients underwent cold-knife conization with suture. This study's essential variables include blood loss, duration of operation, number of pregnancies, type of labor, and age of the patient. The results are calculated based on t-test, Fisher exact test, chi-square, and nonparametric Mann-Whitney tests.

Result: There was no significant difference between the variables studied, including blood loss ( $\mathrm{p}$-value $=0.185$ ). The only significant difference was in the duration of operation ( $\mathrm{p}$-value $=0.000$ ).

Conclusion: Our findings showed no significant difference in the amount of blood loss between the sutured and non-sutured groups. These results also showed that the operation duration was significantly reduced. This result was excepted since there was no need for suturing, and the other stages of the procedure were the same throughout the cold knife conization in both groups. Due to the shorter operation duration, no difference in the amount of postoperative bleeding, and the specific risks of suture, it is suggested to use a non-suture technique for coldknife conization.
\end{abstract}

Keywords: Cervical intraepithelial neoplasia, CIN, cold-knife conization, cervical surgery

\section{ÖZ}

Amaç: Bu çalışmanın amacı soğuk konizasyon sonrası hemostatik suture atılan ve atılmayan yöntemleri karşılaştırmaktır.

Gereç ve Yöntem: Bu çalışma soğuk konizasyon geçiren 172 kadını kapsamaktadır. İlk gruptaki hastalar dikişsiz soğuk konizasyonu, ikinci gruptaki hastalar ise dikişli soğuk konizasyonu geçirmiştir. Bu çalışmadaki temel değişkenler kan kaybı, ameliyat süresi, gebelik sayısı, çocuk doğurma tipi ve hastaların yaşını kapsar. Sonuçlar t-testi, Fisher kesin testi, ki-kare ve parameter dışı Mann-Whitney testlerine göre hesaplanmıştır.

Bulgular: Kan kaybı (p-değeri=0,815) gibi çalışılan değerler arasında anlamlı fark gözlemlenmemiştir. Tek anlamlı fark ameliyat süresinde olmuştur (p-değeri=0,000).

Sonuç: Sütürlü ve sütürsüz konizasyon geçiren olguşlar arasında kan kayıpları arasında anlamlı bir fark yoktur. Ayrıca sonuçlar ameliyat süresinin anlamlı ölçüde kısaldığını göstermiştir. Bu sonuç hemostatik suture hiçbir gerek olmadığını ve her iki grupta da prosedürün diğer aşamaları soğuk konizasyon boyunca aynı olduğu için beklenen bir sonuçtu. Ameliyat süresinin kısa olması ve post-operatif kanama miktarında değişim ya da suture özgü riskler gözlemlenmemesi sebebiyle soğuk konizasyonunda sütürsüz yöntem önerilmektedir.

Anahtar Kelimeler: Servikal intraepitelyal neoplazi, CIN, soğuk konizasyon, servikal cerrahi 


\section{INTRODUCTION}

Pathologically, cervical intraepithelial neoplasia (CIN) is a change in the cervical squamous cell that is confined to the basal layer of the epithelium (1). If left untreated, they can progress to malignancy and become cervical cancer (2). Cervical cancer is the most common cancer in women in developing countries (3). In cases where there is a need for treatment of the lesion, the affected area can be removed by conization $(1,3)$. Studies have shown that cervical conization is as effective as hysterectomies in preventing the spread of Carcinoma in Situ (CIS) (4) and in $90 \%$ of cases improve high-grade CIN $(5,6)$. Cervical conization has long been an accepted method of diagnosing and treating $\mathrm{CIN}$, and despite the development of new methods, classical conization indications are still in place (7). This procedure is performed by various techniques such as the Loop Electrosurgical Excision Procedure (LEEP) or Cold-Knife Cone (CKC) method. Cutting a cone with cold-knife and hemostasis through the suture is one of the most common methods of doing cervical conization (8).

Cold-knife conization is often used for lesions that do not have invasive cancer or are not satisfactory for colposcopy, and most of the disease has spread to the endocervical canal $(8,9)$. In general, cold-knife conization indications include the inability to observe the entire T-Zone, the mismatch between colposcopy and Pap smear, the suspicion of invasive colonoscopic cancer, and the Adenocarcinoma in situ (AIS). The inability to observe the entire T-zone has been the most important indication of cold-knife conization in various studies. The criticism of the cold-knife conization is based on the need for general anesthesia and the risk of complications $(10,11)$. However, numerous reports have shown that the procedure can be performed with minimal complications (12-14).

Cervical conization plays an essential role in dealing with patients with CIN $(2,4)$. The operation of a cone with the cold-knife method is both a diagnostic and a therapeutic approach (5), and its advantage is to provide a tissue specimen to the pathologist for further examination (14). The sample should include all affected areas, including exocervix and endocervix (15). Because all treatments for CIN have a $10 \%$ chance of recurrence, they should be examined by cytology at 6-month intervals and followed by colposcopy if anything abnormal is observed (16).

In the mid-20th century, the hemostatic sutures were added to the cold-knife conization technique to minimize blood loss (17). Since then, using these sutures and their effectiveness has been discussed by many authors (1822). This study compares the effect of these sutures on patients undergoing cold-knife conization.

\section{MATERIAL AND METHOD}

In August 2016-September 2019, a retrospective study was conducted at Gynecology and Obstetrics Department. The procedures were followed according to the regulations established by the Clinical Research and Ethics Committee and to the Helsinki Declaration of the World Medical Association. The study was carried out with the permission of Research Ethics Committee of Beykoz University (Permission granted/CAAE number: 2020/26.2, Decision no: 1). All the patients were given signed informed consent. All patients in this experiment underwent cold knife conization. The study included 172 women who were randomly divided into non-suture and suture groups. In the first group, which was the non-suture group, there were 63 participants, and in the second group, which was the suture group, there were 109 participants.

In the first group (with sutures), a lateral suture was applied on each side of the cervix, and after cutting the sample cone with blade No.11, the raw surface of the cone bed was closed with two figure-of-eights and Sturmdorf sutures. In the second group (without sutures), a coneshaped sample was taken from the cervix with blade No. 11, and the inner and outer flaps were held with two Allis tissue forceps. Meanwhile, a $2 \mathrm{~cm}$ wide-gauze roll soaked in Monsel's solution was pressed onto the conical bed. Monsel's solution was used only for the conical bed. Excessive Monsel's solution was swabbed out, and the gas roll was packed in the upper vagina to prevent the conical bed pack from loosening. The operation was performed for both groups under general anesthesia.

The variables measured in each patient were: age, number of pregnancies, number of labor, type of labor (vaginal, cesarean, or both), prolonged labor, smoking, duration of operation, and blood loss through measuring preoperative hemoglobin $(\mathrm{Hb})$, postoperative $\mathrm{Hb}$, and pathology.

The inclusion criteria for this study were undergoing cold knife conization. The excluding criteria were to use other techniques than cold-knife for conization, undergoing conization in the past by other methods than cold-knife or unwillingness of the patient to participate in the study. After explaining the experiment and describing the procedure, informed consent was obtained from all participants.

\section{Statistical Analysis}

SPSS statistical package program for Windows (Statistical Package for Social Sciences, version 16.0, SPSS Inc. Chicago, Illinois, USA) was used to evaluate the study results. Percent and average calculations in descriptive statistics, chi-square analysis of the relationship between dependent and independent variables, Student $t$ and Mann-Whitney $U$ test analysis methods were used. A value of $p<0.05$ was considered statistically significant. 


\section{RESULTS}

In Table 1, the first two columns are the descriptive statistics. The median and interval between the first and third quartiles were reported for the variables that were not normal. For example, for the non-normal age variable, the mean of this variable is 43 , the first quartile is 38 , and the third quartile is 49 in the non-suture group. We also report these values for the suture group. For a normal variable, its \pm mean, standard deviation, and range of numbers ranging from lowest to highest are reported.

\begin{tabular}{|c|c|c|c|c|}
\hline Variables & & $\begin{array}{l}\text { Non-suture } \\
\text { group }(n=63)\end{array}$ & $\begin{array}{l}\text { Suture group } \\
\quad(n=109)\end{array}$ & P-value \\
\hline Age & $\begin{array}{l}\text { Median } \\
\text { (Interval) }\end{array}$ & $43(38-49)$ & $42(37-49.5)$ & 0.650 \\
\hline $\begin{array}{l}\text { Number of } \\
\text { pregnancies }\end{array}$ & $\begin{array}{l}\text { Median } \\
\text { (Interval) }\end{array}$ & $3(2-4)$ & $3(2-5)$ & 0.736 \\
\hline $\begin{array}{l}\text { Number of } \\
\text { labor }\end{array}$ & $\begin{array}{l}\text { Median } \\
\text { (Interval) }\end{array}$ & $2(2-3)$ & $2(1-3)$ & 0.347 \\
\hline $\begin{array}{l}\text { Duration of } \\
\text { operation }\end{array}$ & $\begin{array}{l}\text { Median } \\
\text { (Interval) }\end{array}$ & $25(25-30)$ & $30(27.5-35)$ & 0.000 \\
\hline Blood loss & $\begin{array}{l}\text { Median } \\
\text { (Interval) }\end{array}$ & $\begin{array}{c}0.90 \\
(0.60-1.40)\end{array}$ & $\begin{array}{c}1 \\
(0.75-1.30)\end{array}$ & 0.185 \\
\hline
\end{tabular}

The normality test was first performed for the quantitative variables reported in Table 1. If the variables are normal in each group, we use an independent T-test to investigate the difference between the suture and non-suture groups. That is, the variable in question should be normal in both the suture and non-suture groups at the same time, and if not in one or both groups, we should use a nonparametric alternative Mann-Whitney test.

After the normalization test, we found that the age, number of pregnancies, number of labor, duration of operation, and blood loss variables are not normal, so we use the Mann-Whitney test for them.

After performing the Mann-Whitney tests, it was found that the variables age, number of pregnancies, number of labor, and blood loss were not significant because their $\mathrm{p}$-value was higher than 0.05 . So for these variables, there is no difference between the suture and non-suture groups.

However, the duration of the operation variable is significant because its P-Value is less than 0.05. So, for this variable, there is a difference between the suture and non-suture groups.

The four qualitative variables of type of labor, smoking, pathology, and prolonged labor, are reported in Table 2. For these variables, the chi-square test was used to investigate the difference between non-suture and suture groups. If more than $20 \%$ of the chi-square test cells have a value of less than 5, then we use Fisher's exact test.

\begin{tabular}{|c|c|c|c|}
\hline Variables & $\begin{array}{c}\text { Non-suture } \\
\text { group }(n=63)\end{array}$ & $\begin{array}{l}\text { Suture group } \\
(\mathrm{n}=109)\end{array}$ & P-Value \\
\hline \multicolumn{3}{|l|}{ Type of labor } & \multirow{5}{*}{0.315} \\
\hline $\begin{array}{l}\text { NSD (Normal } \\
\text { Spontaneous } \\
\text { Delivery) }\end{array}$ & $73(46)$ & $75(68.8)$ & \\
\hline $\begin{array}{l}\text { CS (Caesarean } \\
\text { Section) }\end{array}$ & $6(9.5)$ & $17(15.6)$ & \\
\hline NSD \& CS & $6(9.5)$ & $5(6.4)$ & \\
\hline NOT giving birth & $4(6.3)$ & $12(11)$ & \\
\hline \multicolumn{3}{|l|}{ Smoking } & \multirow{3}{*}{0.868} \\
\hline No-Smoker & $43(68.3)$ & $73(67)$ & \\
\hline Smoker & $20(31.7)$ & $(33) 36$ & \\
\hline \multicolumn{3}{|l|}{ Pathology } & \multirow{8}{*}{0.062} \\
\hline Benign & $23(36.5)$ & $33(30.3)$ & \\
\hline $\begin{array}{l}\text { LSIL (Low } \\
\text { Grade Squamous } \\
\text { Intraepithelial } \\
\text { Lesion) }\end{array}$ & $1(1.6)$ & $9(8.3)$ & \\
\hline $\begin{array}{l}\text { HSIL (High } \\
\text { Grade Squamous } \\
\text { Intraepithelial } \\
\text { Lesion) }\end{array}$ & $26(41.3)$ & $56(51.4)$ & \\
\hline Carcinoma in situ & $7(11.1)$ & $2(1.8)$ & \\
\hline $\begin{array}{l}\text { SCC (Squamous cell } \\
\text { carcinoma) }\end{array}$ & $3(4.8)$ & $5(4.6)$ & \\
\hline $\begin{array}{l}\text { Adenocarcinoma } \\
\text { in situ }\end{array}$ & $2(3.2)$ & $3(2.8)$ & \\
\hline Adenocarcinoma & $1(1.6)$ & $1(0.9)$ & \\
\hline \multicolumn{3}{|l|}{ Prolonged labor } & \multirow{3}{*}{1} \\
\hline Normal time & $60(95.2)$ & $104(95.4)$ & \\
\hline Extended labor time & $3(4.8)$ & $5(4.6)$ & \\
\hline
\end{tabular}

According to the P-values of the Chi-square and Fisher's tests, none of these variables were significant because their P-values were higher than 0.05 . So, in these four variables, there is no difference between non-suture and suture groups.

For the pathology and prolonged labor variables, since more than $20 \%$ of their table cells had a value higher than 5, then we report the P-Value of the Fisher test.

The second and third column in Table 2 also reports the values of descriptive statistics, in which the first number is the number of people in that class in each group (suture and non-suture). The number in parentheses represents the percentage of people in that group. For example, for the type of labor variable, the value of NSD is in 46 participants in the non-suture group, with $73 \%$ of the group, and it is in 75 participants in the suture group, with $68.8 \%$ of the group.

We did not use the preop $\mathrm{Hb}$ and postop $\mathrm{Hb}$ variables, indicating pre- and postoperative $\mathrm{Hb}$ levels in analyses. Instead, we used the blood loss variable, which was the difference between the two variables, since they are pre and post $\mathrm{Hb}$, and their differences show the amount of blood loss in the patient. 
The results showed that the only variable that had a significant difference between the sutured and nonsutured groups was the operation duration variable. This means that there was a significant difference between the duration of operation in the sutured and non-sutured groups. It was also shown that among other factors, such as the amount of blood loss or pathology, there were no significant differences between the sutured and nonsutured groups.

\section{DISCUSSION}

Our study results showed that in the non-suture group, the duration of operation was significantly reduced compared to the suture used group. There were no significant differences between the two groups for other variables, such as blood loss. Our results showed that the operative time was shorter in patients without sutures. This result was expected because the suture stage had not been performed for the non-suture group. All other conization procedures were similar in both groups, and there was no significant difference between them. There was no difference between the qualifications of surgeons, postoperative interventions, and the amount of bleeding.

Many studies have explored different methods and techniques for reducing cold-knife conization complications. The reduction of operation duration for patients treated with non-suture techniques has also been reported in some studies (18-22).

The results of our findings were consistent with those of Tangtrakul et al. (18). In this study, the authors studied 112 patients undergoing cold knife colonization in two groups without sutures (using Monsel's solution) and with sutures. Their findings showed that there was no significant difference in the amount of blood loss between the two groups. They also reported shorter operative times in the non-suture group (18).

In a similar study, the authors compared the use of sutures and Monsel's solution by testing two groups of patients with cone biopsy. Their results showed a lower operative time in the group using the Monsel's solution (19). In another study of 191 participants who underwent conization procedure with cold-knife technique, two methods of cauterization and suture were compared. Their results showed that in patients who used cauterization, there was less bleeding and surgery time than the suture group (20). The results obtained from the amount of blood loss in our study were consistent with those obtained in $(19,20)$. In our study, smoking and non-smoking were not significantly different for either group. These results were consistent with those in (20).
In our study, no differences were found between postoperative complications such as bleeding in the sutured and non-sutured groups. These results were consistent with $(19,20)$. However, these results were inconsistent with the findings of Dane et al. (21) in which the cerclage group was more likely to have late bleeding.

Consistent with our results, another study by Letícia Rossi Bueno et al. (22) investigated the cold-knife conization with and without sutures and found similar results. The authors found no difference in bleeding between the two groups of with and without sutures. They also reported shorter operation times in the non-suture group. Because of no difference is found in the bloodloss of the two groups, the reduction in operation time and the different risks of suture $(5,10,18)$, it is recommended to use a nonsuture technique.

\section{CONCLUSION}

In this study, we investigated the difference between non-suture and suture groups in patients undergoing cold-knife conization. In our findings, the operative time was shorter in the non-suture group. This reduction was only due to the reduction in suture time, and other procedures, such as anesthesia or hemostasis, were similar in both groups and had no effect on the results. We observed no difference in blood loss and the need for postoperative interventions between the two non-suture and suture groups. Therefore, due to the findings of our study, such as no difference in postoperative bleeding and the reduction in operation time, it is recommended to use a non-suture technique.

\section{ETHICAL DECLARATIONS}

Ethics Committee Approval: The study was carried out with the permission of Research Ethics Committee of Beykoz University (Permission granted /CAAE number: 2020/26.2, Decision no: 1).

Informed Consent: Because the study was designed retrospectively, no written informed consent form was obtained from patients.

Referee Evaluation Process: Externally peer-reviewed.

Conflict of Interest Statement: The authors have no conflicts of interest to declare.

Financial Disclosure: The authors declared that this study has received no financial support.

Author Contributions: All of the authors declare that they have all participated in the design, execution, and analysis of the paper, and that they have approved the final version. 


\section{REFERENCES}

1. Mathevet P, Dargent D, Roy M, Beau G. A randomized prospective study comparing three techniques of conization: cold knife, laser, and LEEP. Gynecol Oncol 1994; 54: 175-9.

2. Larsson GÖ, Gullberg B, Grundsell HA. A comparison of complications of laser and cold knife conization. Obstetr Gynecol 1983; 62: 213-7.

3. Mathevet P, Chemali E, Roy M, Dargent D. Long-term outcome of a randomized study comparing three techniques of conization: cold knife, laser, and LEEP. Eur J Obstetr Gynecol Reproduct Biol 2003; 106: 214-8.

4. Duggan BD, Felix JC, Muderspach LI, et al. Cold-knife conization versus conization by the loop electrosurgical excision procedure: a randomized, prospective study. Am J Obstetr Gynecol 1999; 180: 276-82.

5. Reich O, Lahousen M, Pickel H, Tamussino K, Winter R. Cervical intraepithelial neoplasia III: long-term follow-up after cold-knife conization with involved margins. Obstetr Gynecol 2002; 99: 193-6.

6. Reich O, Pickel H, Lahousen M, Tamussino K, Winter R. Cervical intraepithelial neoplasia III: long-term outcome after cold-knife conization with clear margins. Obstetr Gynecol 2001; 97: 428-30.

7. Larsson G, Alm P, Grundsell H. Laser conization versus cold knife conization. Surg Gynecol Obstetr 1982; 154: 59-61.

8. Huang LW, Hwang JL. A comparison between loop electrosurgical excision procedure and cold knife conization for treatment of cervical dysplasia: residual disease in a subsequent hysterectomy specimen. Gynecol Oncol 1999; 73: 12-5.

9. Naumann RW, Bell MC, Alvarez RD, et al. LLETZ is an acceptable alternative to diagnostic cold-knife conization. Gynecol Oncol 1994; 55: 224-8.

10. Giacalone PL, Laffargue F, Aligier N, Roger P, Combecal J, Daures JP. Randomized study comparing two techniques of conization: cold knife versus loop excision. Gynecol Oncol 1999; 75: 356-60.

11. Girardi F, Heydarfadai M, Koroschetz F, Pickel H, Winter R. Coldknife conization versus loop excision: histopathologic and clinical results of a randomized trial. Gynecol Oncol 1994; 55: 368-70.

12. Oyesanya OA, Amerasinghe C, Manning ED. A comparison between loop diathermy conization and cold-knife conization for management of cervical dysplasia associated with unsatisfactory colposcopy. Gynecol Oncol 1993; 50: 84-8.

13. Klaritsch P, Reich O, Giuliani A, Tamussino K, Haas J, Winter R. Delivery outcome after cold-knife conization of the uterine cervix. Gynecol Oncol 2006; 103: 604-7.

14. Saidi MH, Setzler Jr FD, Sadler RK, Farhart SA, Akright BD. Comparison of office loop electrosurgical conization and cold knife conization. J Am Assoc Gynecol Laparoscopists 1994; 1: 135-9.

15. Mohamed-Noor K, Quinn MA, Tan J. Outcomes after cervical cold knife conization with complete and incomplete excision of abnormal epithelium: a review of 699 cases. Gynecol Oncol 1997; 67: 34-8.

16. Demeter A, Sziller I, Csapo Z, Szánthó A, Papp Z. Outcome of pregnancies after cold-knife conization of the uterine cervix during pregnancy. Eur J Gynecol Oncol 2002; 23: 207-10.

17. Hillemanns P, Kimmig R, Dannecker C, et al. LEEP versus cold knife conization for treatment of cervical intraepithelial neoplasias. Zentralblatt fur Gynakologie 2000; 122: 35-42.

18. Tangtrakul S, Srisupundit S, Linasmita V, et al. A randomized study comparing suture with non-suture cold-knife conization. J Obstetr Gynaecol 1995; 21: 587-91.

19. Gilbert L, Saunders NJ, Stringer R, Sharp F. Hemostasis and cold knife cone biopsy: a prospective randomized trial comparing a suture versus non-suture technique. Obstetr Gynecol 1989;74: 6403.
20. Kamat AA, Kramer P, Soisson AP. Superiority of electrocautery over the suture method for achieving cervical cone bed hemostasis. Obstetr Gynecol 2003; 102: 726-30.

21. Dane C, Dane B, Cetin A, Erginbas M. Haemostasis after coldknife conisation: a randomised prospective trial comparing cerclage suture versus electro-cauterisation. Australian and New Zealand J Obstetr Gynaecol 2008; 48: 343-7.

22. Bueno LR, Binda M, Monego H, et al. Randomized clinical trial comparing cold knife conization of the cervix with and without lateral hemostatic sutures. Int J Surg 2015; 18: 224-9. 